ISSN: 2146-3042

DOI: $10.25095 /$ mufad.673727

\title{
Makroekonomik Göstergelerin Sermaye Yapısı Üzerindeki Etkisi: İmalat Dışı Sektörler Üzerinde Bir Araştırma*
}

\section{$\ddot{O Z Z E T}$}

İsletmelerin sermaye yapısını etkileyen çok farklı etkenler bulunmaktadır. Bu çalışmada TCMB sektörel bilançoları kullanılarak imalat dışı sektörlerde temel makroekonomik göstergelerin sermaye yapısı üzerindeki etkisi araşstırılmıştır. Bu amaçla 2005-2016 yılların kapsayan 12 yıllık dönemde tam verilerine ulaşılan imalat dışı 9 sektörün kaldıraç oranları ile aynı döneme ait temel makroekonomik göstergeler kullanılarak regresyon analizi yapılmıştır. Kaldıraç oranları bağımlı değişken, temel makroekonomik göstergeler ise bağımsı değişken olarak kullanilmıştır. Yapılan analiz sonucunda; analiz kapsamındaki birçok sektörde GSYH'daki değişimler ile döviz kurundaki değişimlerin sektörlerin sermaye yapılar üzerinde pozitif yönde anlamlı etkiye sahip olduğu, bazı sektörlerde faiz oranındaki değisimlerin ise sermaye yapılar üzerinde negatif yönde anlaml etkiye sahip olduğu sonucuna ulaşılmıştır. Analize konu olan hiçbir sektörde TÜFE'nin sermaye yapısı üzerinde anlamlı bir etkiye sahip olmadiğ tespit edilmişstir.
\end{abstract}

Anahtar Kelimeler: Sermaye Yapısı, Kaldıraç Oranı, Makroekonomik Göstergeler

JEL Siniflandırması: M40, M41, G10

\section{The Effect Of Macroeconomic Indicators On The Capital Structure: A Research On} Non-Manufacturing Sectors

\section{ABSTRACT}

There are many different factors affecting the capital structure in businesses. In this study, the effect of basic macroeconomic indicators on capital structure in non-manufacturing sectors using the Central Bank of the Republic of Turkey sectoral balance sheets is investigated.For this purpose, regression analysis for the 12 - year period of 2005-2016 for businesses with complete data is performed using the leverage ratios of 9 non manufacturing sectors and the basic macroeconomic indicators.Leverage ratios variableis used as dependent variables, while basic macroeconomic indicators variableis used as an independent variable.As a result of the analysis; it is concluded that the changes in the gross domestic product and the changes in the exchange rate have a significant positive effect on the capital structures of the sectors, while the change in the interest rates in some sectors has a negative effect on the leverage ratios. The results suggest that consumer price index has no significant effect on capital structure in any sector subject to analysis.

Keywords: Capital Structure, LeverageRatio, Macroeconomic Indicators

Jel Classification: M40, M41, G10

* Makale Gönderim Tarihi: 18.4.2019, Makale Kabul Tarihi: 10.05. 2019, Makale Türü: Araştırma Makalesi

* Doç. Dr., Ondokuz Mayıs Üniversitesi, Turizm Fakültesi, eyilmaz@ omu.edu.tr, Orcid ID: 0000-0002-2491446X

** Dr. Öğr. Üyesi, Siirt Üniversitesi, İktisadi ve İdari Bilimler Fakültesi, tunay_aslan@hotmail.com, Orcid ID: 0000-0002-0363-6691 


\section{GİRIŞ}

İşletmelerin temel amacının piyasa değerini en üst düzeye çıkarmak olduğu günümüzde yaygın kabul edilen bir görüştür. İşletme değerinin maksimizayonu için sermaye maliyetinin de minimum düzeyde tutulması ve bunu sağlayacak optimum sermaye yapısının belirlenmesi için çeşitli teoriler geliştirilmiştir. Bu konuda farklı görüşlerin olmasının nedenlerinden biri de optimum sermaye yapısının sektörden sektöre, işletmeden işletmeye farklılık gösterebilmesinden kaynaklanmaktadır. İşletmelerin sermaye yapısını etkileyen faktörlerden bir tanesi de temel makrokekonomik göstergelerdir. Gayrisafi Yurtiçi Hasıla (GSYH), döviz kuru, faiz oranı ve Tüketici Fiyat Endeksi (TÜFE) gibi temel makro ekonomik göstergelerdeki değişiklere bağlı olarak işletmelerin sermaye maliyetlerinde değişimler olmakta, bu değişimler de işletmelerin sermaye yapısını etkilemektedir.

İşletmeler finansman ihtiyaçlarını̈zsermaye kullanarak ya daborçlanarak temin etmektedir. Buna göre sermaye yapısı işletmelerin özsermayeleriile borçları arasındaki ilişkiyi açıklamaktadır. Sermaye maliyeti yatırımcılara ait uzun vadeli borçları ile öz sermaye getiri oranını temsil etmektedir (Ata ve A $\breve{g}, 2010: 46$ ).

İşletmelerin kuruluş fikri ile ortaya çıkan ve yaşamı boyunca devam eden toplam sermaye ihtiyacı ve sermaye yapısının oluşturulmasında borç ve öz kaynak bileşenlerinin dağılımı finans literatüründe daima tartışma konusu olmuştur. Optimal sermaye yapısının nasıl olması gerektiğine dair 1958 yılında Modigliani-Miller'le başlayan net gelir yaklaşımı, net faaliyet gelir yaklaşımları gibi klasik yaklaşımlarla birlikte modern yaklaşımlar olarak nitelendirilen dengeleme teorisi ve finansal hiyerarşi gibi güncel yaklaşımlar oluşturulmuştur (Kisakürek ve Aydın, 2013:102).

İşletmelerin almış olduğu finansal kararlar işletmeler için hayati öneme sahiptir. Sermaye yapısının oluşumu ile ilgili alınan yanlış finansal kararlar işletmeyi ekonomik sıkıntıya sokabilmektedir. Bu nedenle işletme yönetimi işletmenin sermaye yapısını işletme değerini maksimize edecek şekilde oluşturmalıdır. Literatürde yapılan ampirik çalışmalar optimum sermaye yapısından bahsetmiş olsa da şu ana kadar finans yöneticilerinin optimum borç seviyesine ulaşmada kullanabileceği somut yöntem bulunmamaktadır. Bu bağlamda finans bilimi tercih edilen finansman karmasının işletme değeri üzerinde etkisini anlamaya çalışmaktadır (Ata ve Ağ, 2010:46).

İşletmeler için büyük öneme sahip olan sermaye yapısının belirleyicileri birçok çalışmanın konusu olmuştur. Ancak makroekonomik göstergelerin sermaye yapısı üzerindeki etkileri konusundaki çalışmalar oldukça sınırlıdır. Bu çalışmada, imalat dışı sektörlerde temel makroekonimik göstergelerdeki değişikliklerin sermaye yapısındaki değişiklikler üzerindeki etkisi araştırılmaktadır. Bu amaçla Türkiye Cumluriyeti Merkez Bankası (TCMB) sektörel bilançoları kullanılarak, 2005-2016 dönemini kapsayan 12 yıllık kaldıraç oranları ile aynı döneme ait temel makroekonomik göstergelerle regresyon analizi gerçekleştirilmiştir. Regresyon analizinde temel makroekonomik göstergeler bağımsız değişken, sermaye yapısının göstergesi olarak sektörlerin kaldıraç oranları da bağımlı değişken olarak kullanılmıştır. 


\section{SERMAYE YAPISI KAVRAMI}

Literatürde sermaye kavramına ilişkin değişik tanımlamalara rastlamak mümkün olmakla beraber en basit ifade ile sermaye, işletmelerin ekonomik fayda sağlamak amacıyla kullandıkları ve bilançonun aktif kısmını oluşturan varlıklar ile bu varlıkların edinilmesi için dışarıdan sağlanan kısa ve uzun vadeli kaynaklar arasındaki fark olarak tanımlanmaktadır. İşletme yöneticilerinin varlıkları edinimlerindeki uygulamış oldukları politikalar işletmenin değerini etkilemekte olup işletme performansının artmasında pozitif katkısı bulunmaktadır(Halaç ve Durak, 2013:497).

İşletmelerin varlıklarını finanse etmek için kullanmış olduğu imtiyazlı hisse senetleri, borçlar, dağıtılmayan karlar, adi hisse senetleri gibi enstrümanların maliyeti sermaye maliyeti olarak ifade edilmektedir. Sermaye maliyeti hesaplanırken uzun vadeli yabancı kaynaklar ile öz sermayenin kendi içerisindeki ağırlıkları dikkate alınır. İşletmelerin iki finansman kaynağı olan borçlar ve öz sermayenin göstermiş olduğu değişim sermaye maliyetini etkilemekte olup bu da sermaye maliyetini önemli hale getirmektedir. Belirlenen sermaye yapısı sermaye maliyetini ve işletme değerini etkiliyor ise işletmelerin sermaye maliyetini minimum yapacak optimal sermaye yapısını bulması gerekmektedir (Öcal, 2018:22; Ay, 2018:18; Şahin, 2012:15).

İşletmelerin varlıklarını finans etmede hangi kaynakları kullanacağı önem arz etmekte olup işletmeler sahip oldukları varlıklarını borçlanma veya öz kaynaklar ile finanse etmektedir. Kullanılan kaynakların kendi içerisinde karışımı sermaye yapısı olarak ifade edilmektedir. Bir diğer ifade ile işletmeler tarafindan kullanılan her türlü finansal kaynağın göreceli tutarına sermaye yapısı denmektedir (Halaç ve Durak, 2013:500).

İşletmelerin sermaye yapısı oluşturulurken optimal sermaye yapısında kalınması amaçlanmaktadır. İşletmelerin varlıkları öz sermaye ve borçlanma yolu ile tedarik edilen kaynaklardan oluşmakta olup genel olarak borçlanma yoluyla tedarik edilen kaynağın maliyeti öz kaynaklara göre daha düşüktür. Bu nedenle borçların arttırılması yolu ile öz kaynaklardan sağlanan fonların karlılığı yükselteceği belirtilmiş olsa da bir noktadan sonra yüksek borçluluk oranları işletmenin riskinin artmasına sebep olacaktır (Takbaş,2018:76).

İşletme yöneticilerinin amacı işletmenini ihtiyacı olan fonların ne kadarlık kısmının borç alarak ne kadarlık kısmının ise öz kaynaklar ile karşılanacağına ait optimal seviyeyi ayarlamaktır. Sermaye yapısını oluşturmada optimum noktanın sağlanlanması amaçlanmakta olup bu noktada kullanılan kaynakların ortalama sermaye maliyeti minimum olması gerekmektedir (Yener ve Karakuş, 2012:102).

Optimum sermaye yapısıyla ilgili teoriler işletmelerde borç/öz kaynak kombinasyonunu nasıl olması gerektiğini ve ne gibi değişkenlerden etkilendiğini ortaya koymayı amaçlamaktadır. Klasik sermaye yapısı teorileri daha çok borç öz kaynak kombinasyonunu değiştirmek suretiyle işletme değerini değiştirmenin mümkün olduğunu açıklamaya çalışan teorilerdir. Modern sermaye teorileri ise işletmelerde sermaye yapısını belirleyen değişkenlerin belirlenmesini ortaya koymaya yönelik olarak geliştirilmiştir. Buna göre işletmelerde sermaye davranışlarını açıklayan teorileri klasik ve modern sermaye yapısı teorileri olarak iki grupta incelemek mümkündür (Karadeniz, 2008:16). 
Tablo 1. Sermaye Yapısı Teorileri

\begin{tabular}{|l|l|}
\hline Klasik Sermaye Yapısı Teorileri & Modern Sermaye Yapısı Teorileri \\
\hline Net Gelir Yaklaşımı & Dengeleme Kuramı \\
\hline Net Faaliyet Geliri Yaklaşımı & Finansman Hiyerarşisi Kuramı \\
\hline Geleneksel Yaklaşım & Temsil maliyet kuramı \\
\hline Modigliani ve Miller Yaklaşımı & Asimetrik Bilgi Kuramı \\
\hline & İşaret Etkisi Kuramı \\
\hline
\end{tabular}

Kaynak: Tablo yazarlar tarafindan oluşturulmuştur.

Finans dünyasında 1950'li yıllardan bu yana çeşitli varsayımlara dayanarak geliştirilen klasik sermaye yaklaşımları işlemenin sermaye yapısını, sermaye maliyetini ve piyasa değerini etkileyip etkilemediğini anlamaya yöneliktir. Örneğin finansal kaldıracın etkisini dikkate alan 'Net Gelir Yaklaşımı'na göre işletmeler sermaye yapısını değiştirerek sermaye maliyetini düşürüp piyasa değerini yükseltebilir. "Net Faaliyet Geliri Yaklaşımı" ise aksine bir işletmenin sermaye yapısının ortalama sermaye maliyetini ve piyasa değerini etkilemeyeceğini savunmaktadır (Demirhan, 2009:678).

"Geleneksek Yaklaşım” olarak kabul edilen görüşe göre; sermaye yapısı işletmenin sermaye maliyetini ve piyasa değerini etkilemekte olup işletmeler için tek bir optimal sermaye yapısı bulunduğunu savunmaktadır. "Modigliani ve Miller Yaklaşımı"na göre; vergi unsurunun bulunmadığı sermaye piyasalarında işletmenin piyasa değeri işletmenin sermaye yapısından bağımsız olup optimal sermaye yapısına ulaşılmayacağını savunmaktadırlar (Demirhan, 2009:678).

Modigliani ve Miller sermaye yapısı üzerine modern teoriler geliştirmişlerdir. Bunlar; dengeleme, finansman hiyerarşisi, temsil maliyeti, asimetrik bilgi ve işaret etkisi kavramları olup söz konusu teorilerde işletmelerin sermaye yapısı kararları ve finansman yapı tercihlerini belirleyen değişkenler ele alınmıştır. Dengeleme teorisi, yabancı kaynak kullanmanın sağlamış olduğu vergi avantajı ile finansal sıkıntı arasında dengeleme olması gerektiğini savunmaktadır (Akkaya, 2008:4). İşletmelerin yabancı kaynak ile öz sermaye arasında optimal oranı yakalaması gerektiği önerilmektedir. Bu teoriye göre hedef borç oranın işletmeden işletmeye göre farklılık arz ettiğini savunmaktadır. İşletme güvenli, maddi duran varlıkları yüksek, vergilendirilebilir karı yüksek ise borç oranı yüksek olmalıdır. Riskli, maddi duran varlıkları az ve karsız işletmeler ise öz kaynakları ile finanse olmalıdır (Brealeyvd, 1999:862).

Finansman hiyerarşisi teorisine göre; yeni yatırımlarını finanse etmek isteyen yatırımcılarsermaye yapısını oluştururken öncelikle otofinansmana daha sonra borçlara son olarak ise tahvil ihracına başvurmalıdır. İşletmelerin önceden belirleyecekleri optimal borç/öz sermaye oranı bulunmamaktadır. Borçlanma oranı işletmede yaratılan kaynakların düzeyine ve yatırım harcamalarına göre işletmeden işletmeye farklılık göstermektedir (Okuyan ve Taşç1, 2013:61).

Temsil maliyeti kuramı yaklaşımına göre hissedarlar ile yöneticiler ve hissedarlar ile alacaklılar arasında çıkar çatışmasının olduğu belirtilmektedir. $\mathrm{Bu}$ kurama göre çıkar gruplarının işletmeye yüklediği maliyetlerinişletmelerin sermaye yapısı üzerinde etkili olduğu 
ifade edilmektedir (Myers, 1977:147; Fama, 1980:289). Bir diğer yaklaşım olan asimetrik bilgi kuramına göre ise işletme yöneticileri ile işletme dışında yer alan çıkar guruplarının işletme ile ilgili sahip oldukları bilginin farklılığına dayanır. Buna göre işletmenini sermaye yapısı işletme yöneticilerinin alacakları karara göre oluşacaktır. İşletme dışındaki çıkar gurupları işletme yöneticileri ile aralarındaki bu bilgi farklılığını gidermeye çalışacaklarını ileri süren yaklaşımdır (Topal, 2006:51). İşaret etkisi kuramına göre işletmenin borç kullanımındaki artışın piyasaya işletmenin mali durumunun iyi olduğunu rapor olarak bildirdiği durumdur. Çok karlı ve büyüme eğilimi gösteren işletmeler daha az karlı ve büyüme eğilimi göstermeyen işletmelere göre daha çok borçlanmaktadır (Ata ve Ağ, 2010:49).

\section{LITERATÜR TARAMASI}

Finansdünyasında sermaye yapısını etkileyen faktörlerin belirlenmesine yönelik ampirik çalışmalar incelendiğinde yapılanakedemik çalı̧̧maların ağırlıklı olarak ABD'de yapıldığ 1 görülmekte olup son zamanlarda gelişmekte olan ülkelerde de bu tür çalışmalara rastlanılmıştır. Çalışmanın bu bölümünde sermaye yapısını etkileyen faktörlerin araştırıldığı temel çalışmalara özet olarak yer verilecektir.

Titman ve Wessels (1988), araştırmalarında işletmelerin varlık büyüklüğü ile uzun vadeli borçların kaynaklara oranı arasında pozotif ilişki olduğunu ortaya koymuştur.

Gorg ve Strobl (2001), işletmelerin iş gücü talebi ile sermaye yapısı arasında ilişki olup olmadığını araştırmışlardır. Çalışmada İrlanda'da elektronik sektöründe faaliyet gösteren 37 işletmenin mali verileri kullanılmıştır. Sonuç olarak iş gücü talebi kararlarının işletmelerin sermaye yapısından bağımsız olduğu sonucuna varmışlarıdır.

Bevan ve Danbolt (2002), yaptıkları çalışmalarda ise işletme büyüklüğü ile kısa vadeli borçlanma oranları arasında negatif yönlü, uzun vadeli borçlanma oranları arasında ise pozotif yönlü ilişki olduğunu saptamışlardır.

Lööf (2003), ise yaptığ1 çalışmada farklı ülkelerde ve büyüklüklerde yer alan işletmelerin sermaye yapılarını etkileyen değişkenleri araştırmıştır. Sonuçta işletmelerin farklı ekonomik sistem ve büyüklükte olsalar bile sermaye yapılarını belirleyen etkenlerin aynı olacağ1 sonucuna varmıştır. Araştırmada ABD, İsveç, İngiltere işletmeleri incelenmiş ve sermaye yapısını etkileyen faktörlerin finansal sektörün büyüklüğü, vergilendirme ve sermaye arzı koşullarına bağlı olduğu sonucuna varmıştır.

İsmail ve Eldomiaty (2004), yaptıkları çalışmada geçmiş yıllarda sermaye yapısına etki eden tüm oranları bir araya getirerek işletmelerin finansal yapılarına etki eden en uygun değişkenleri bulmaya çalışmışlardır. Araştırma sonucunda finansal hiyerarşi kuramının Mısır'da etkili olduğu ve sermaye yapısının belirlenmesinde piyasa riski, vergi istisnaları, iflas riski ve işletmenin büyüme oranlarının etkili olduğu sonucuna varmışlardır.

Medeiros ve Daher (2004), Brezilya menkul kıymetler borsasında işlem gören 132 işletme üzerinde yaptıkları çalışmada, işletmelerin sermaye yapısının belirlenmesinde finansal hiyaraşi kurumanın belirleyici olup olmadığını araştırmışlardır. Sonuç olarak araştırmaya konu olan işletmelerin sermaye yapısının belirlenmesinde finansal hiyaraşi kuramı belirleyici olduğu sonucuna varılmıştır. 
Adjunct, Eidet, Frydenberg ve Grosas (2008), ise İngiltere'de faaliyet gösteren 308 gayrimenkülşirketinin sermaye bileşenin belirleyicileri üzerine araştırma yapmışlardır. Yapılan analiz sonucunda karlılık ile borçlanma oranları arasında pozotif ilişki saptamışlardır.

Başaran (2008), yaptığı çalışmada, hisseleri İMKB'de işlem gören 16 adet otomotiv ve otomotiv yan sanayi işletmesinin sermaye yapılarını etkileyen faktörleri inceleyerek, işletmeye özgü faktörleri belirlemiştir. Çalışma sonucunda, literatürdeki karlılıkları artan işletmelerin iç finansmana yöneleceklerini ve bundan dolayı borç oranlarının azalacağını savunan finansman hiyerarşisi kuramını desteklediği belirlemiştir.

Akkaya (2008), çalışmasında İMKB'de işlem gören deri-tekstil işletmelerin sermaye yapısı, varlık ve karlılık değişkenleri arasında neden sonuç ilişkisi araştırılmış olup uygulamada deri- tekstil işletmelerinin 1997-2006 yılları arasındaki finansal verileri incelenmiştir. Çalışmada TobinQ ve kaldıraç oranları işletmenin sermaye yapısının değişkenleri olarak kullanılmış diğer bağımsız değişkenlerin bu iki değişkeni etkileme gücü araştırılmıştır. Yapılan analiz sonucunda bağımsız değişkenlerin işletmenin sermaye yapısının oluşumunda pozitif etkisinin olduğu sonucuna varılmıştır.

Vasiliou ve Daskalakis (2009), işletmelerin sermaye yapısı ile hisse senetleri arasındaki ilişkinin tespitine yönelik çalışma yapmışlardır. Uygulama için Yunan borsasında faaliyet gösteren 89 işletmenin verilerinden faydalanılmıştır. Sonuç olarak işletmelerin uzun dönem borç kullanımına istekli olmadığı ve temel olarak işletmelerin sermaye yapılarının öz kaynaklardan oluştuğu sonucuna varmışlardır.

Karadeniz, Kaplan ve Günay (2009), yaptıkları çalışmada, halka açık turizm işletmelerinde sermaye yapısı kararlarının kârlılığa etkisini araştırmışlardır. Yapılan analiz sonucunda, turizm işletmelerinde kısa vadeli kaldıraç ile toplam kaldıracın, net kâr marjı, aktif kazanç gücü ve aktif kârlılığı üzerinde negatif etkisi olduğunu saptamışlardır.

Demirhan (2009), yaptığı çalışmada İMKB'de işlem gören hizmet sektörü işletmelerinin sermaye yapısını belirleyen faktörleri panel veri yöntemi ile incelemiştir. Sonuç olarak hizmet işletmelerinin sermaye yapısını etkileyen en önemli faktörlerin karlılık, işletme büyüklüğü, işletmenin varlık ve likidite yapısı olduğuna varılmıştır.

Terim ve Kayalı (2009), yaptıkları çalışmada Türkiye'de imalat sanayisinde faaliyet gösteren işletmelerin sermaye yapılarına ilişkin kararları almalarındaki faktörleri incelemişlerdir. Araştırmaya konu olan işletmelerin karlılık, net sabit varlıklar, büyüme fırsatları ile sermaye yapıları arasında anlamlı ilişki olduğu sonucuna varmışlardır.

Clark, Francis ve Hasan (2009), yaptıkları çalışmada sermaye yapılarının oluşumunda dengeleme kurumanın hem gelişmiş hem de gelişmekte olan ülkelerde 40 ülke için ortaya koymuştur. De Mederios ve Daher (2005), tarafindan yapılan başka bir çalışmada Brezilya'da işletmelerde sermaye yapılarının oluşumunda finansal hiyerarşi teoreminin geçerli olduğu sonucuna varmışlardır.

Sheikh ve Wang (2011), yaptıkları çalışmalardında Pakistan borsasında işlem gören imalat ve sanayi sektöründe faaliyet gösteren 160 işletmenin sermaye yapısını etkileyen değişkenleri işletmelerin 2003-2007 yılları verilerini esas alarak incelemişlerdir. Kısa vadeli 
borçların toplam yükümlülükler içindeki payının yüksek olmasından dolayı bağımlı değişken olarak kaldıraç oranını kullanmıştır. Yapılan araştırma sonucunda karlılık ve likitide ile kaldıraç oranı arasında negatif yönlü ilişki bulmuşlardır.

Cortez ve Sunato (2012), çalışmalarında Japonya'da imalat ve sanayi sektöründe faaliyet gösteren 21 adet işletmenin sermaye yapısını belirleyen değişkenleri incelemişlerdir. Yapılan çalışma sonunda borç/öz sermaye bağımlı değişkeni ile büyüme arasında anlamlı bir ilişki bulamamışlardır.

Anwar (2012), Pakistan Borsasında işlem göre toplam 199 işletmenin sermaye yapısını incelemiş araştırmaya konu olan işletmelerin sermaye yapılarını oluştururken finansal hiyerarşi kuramını takip ettiği sonucuna varmıştır.

Barbosa, Costa, ve Funchal (2012), Brezilyada yaptıkları çalışmada özelleştirme programının işletmelerin sermaye yapılarına etkisi olup olmadığını araştırmışlardır. Yapılan araştırma sonucuna göre işletmelerin özelleştirme öncesine göre kaldıraç oranlarının \%10-15 oranında arttığı sonucuna varmışlarıdır.

Kısakürek ve Aydın (2013), yaptıkları çalışmada Borsa İstanbul'da faaliyet gösteren işletmelerin sermaye yapısı ile karlılıkları arasında bir ilişkinin olup olmadı̆̆ 1 kriz yılları dikkate alınarak incelenmiştir. Uygulamada Borsa İstanbul'da 1992-2010 yılları arasında faaliyet gösteren 104 işletmenin bilançosu ve gelir tablosu incelenmiştir. Sonuç olarak işletmelerin kriz dönemlerinde sermaye yapılarında öz kaynakla finanse edildiği sonucuna varılmıştır.

Sarığlu, Kurun ve Güzeldere (2013), çalışmalarında İMKB'de işlem gören ve çimento, otomotiv ve bilişim sektöründe faaliyet gösteren işletmelerin sermaye yapısı kararlarını etkileyen değişkenleri incelemiştir. Uygulama verileri 2007-2011 dönemlerine ait işletmelerin bilançolardan elde edilen finansal oranlar panel veri yöntemi ile incelenmiştir. Araştırma sonucunda işletmelerin sermaye yapısının oluşumunda dengeleme kuramını tercih ettiği saptanmıştır.

Abdioğlu ve Deniz (2015), yaptıkları çalışmada İMKB' de işlem gören işletmelerin sermaye yapılarının oluşmasındaki faktörlerin neler olduğunu araştırmışlardır. Uygulama 2008 krizi sonrası imalat sanayi işletmelerine ait 5 yıllık 188 işletme üzerinde gerçekleştirilmiştir. Sonuç olarak araştırmaya konu olan işletmelerin sermaye yapısının oluşturulmasında finansal hiyerarşi teoremini benimsedikleri sonucuna varılmıştır.

Öcal (2018), yaptığı tez çalışmasında, TCMB sektörel bilançolarını kullanarak imalat sanayi sektörlerinde iktisadi parametrelerin sermaye yapısı üzerindeki etkisini araştırmıştır. Araştırma sonucunda, imalat sanayi sektörlede büyük kısmının sermaye yapılarının GSYH ve faizden istatistiksel olarak anlamlı bir şekilde etkilenirken, döviz kuru iki sektörü ve enflasyon ise tek sektörü istatistiksel olarak anlamlı şekilde etkilediğini belirlemiştir. 


\section{METODOLOJI}

Bu çalışmada Türkiye Cumhuriyeti Merkez Bankası (TCMB) sektörel bilançolarından faydalanılarak, imalat dışı sektörlerde bazı temel makroekonomik değişkenlerin sermaye yapısı üzerindeki etkisi araştırılmıştır. Uygulamada doğrusal regresyon analizi kullanılmıştır. Doğrusal regresyon modelinde bağımsız değişken ile bağımlı değişken(ler) arasındaki neden sonuç ilişkisini ortaya koyar. Regresyon analizi ile bağımsız değişkenlerin bağımlı değişkenleri ne şekilde etkilediğini ve bağımlı değişkendeki değişimin ne kadarlık kısmının bağımsız değişkenlerden kaynaklandığı ortaya konulmaktadır.

Bir kütledeki $\mathrm{X}$ ve $\mathrm{Y}$ değişkenleri arasındaki doğrusal ilişki aşağıdaki regresyon modeli ile gösterilebilir:

$\mathrm{Y}=\mathrm{b}_{0}+\mathrm{b}_{1} \mathrm{X}+\mathrm{e}$

Y: Bağımlı değişken (bu çalışmada kaldıraç oranı),

X: Bağımsız değişken (bu çalışmada temel makroekonomik parametreler),

bo: bağımsız değişkenin sıfır olması durumunda bağımlı değişkenin alacağı değer,

$\mathrm{b}_{1}$ : Regresyon katsayısı,

e: Hata terimi

Regresyon analizinde enflasyon oranı (TÜFE), döviz kuru, GSYH ve faiz oranları bağımsız değişken olarak yer almıştır. Eğitim, sağlık, gayrimenkul, inşaat, tarım ormancılık ve hayvancılık, madencilik ve taş ocakçılığı, ulaştırma ve depolama, konaklama ve yiyecek hizmetleri, toptan ve perakende ticaret (motorlu kara taşıtlarının ve motosikletlerin onarımı) sektörlerinin kaldıraç oranları ise bağımlı değişken olarak kullanılmıştır.

\subsection{Veri Seti ve Değişkenler}

Türkiye'de makroekonomik göstergelerin imalat dışı sektörlerin sermaye yapısı üzerindeki etkisini gösteren bir çalışmaya rastlanmadığından analiz için imalat dışı sektörler seçilmiştir. Analiz için 2005-2016 yıllarını kapsayan dönemde tam verilerine ulaşılan imalat dış1 9 sektör seçilmiştir. Yıllar itibarı ile değişiklik göstermekle birlikte, 2016 yılında sektörler bazında inceleme konusu işletmelerin sayısı 4698 adet olmuştur. İncelenen işletme sayısının sektörel dağılımı aşağıda belirtilmiştir. 
Tablo 2. 2016 Yılı İtibarı ile Araştıramya Konu Edilen İşletme Sayısı

\begin{tabular}{|l|c|}
\hline Sektörler & Firma Sayısı \\
\hline Tarım Orman Balıkçılık & 166 \\
\hline Madencilik Ve Taşocağı & 106 \\
\hline Elektrik, Gaz, Buhar ve Sıcak Su Üretimi & 319 \\
\hline İnşaat & 497 \\
\hline Toptan Perakende Ticaret & 2.387 \\
\hline Konaklama Ve Yiyecek Hizmetleri & 551 \\
\hline Ulaştırma ve Depolama & 343 \\
\hline Gayrimenkul Faaliyetleri & 111 \\
\hline Eğitim & 67 \\
\hline İnsan Sağlı̆̆ ve Sosyal Hizmet Faaliyetleri & 151 \\
\hline Toplam & $\mathbf{4 6 9 8}$ \\
\hline
\end{tabular}

\subsubsection{Bağımsız Değişkenler}

Bağımsız değişkenlerden enflansyon oranı (TÜFE) ve Gayrisafi Yurtiçi Hasıla (GSYİH) Türkiye İstatistik Kurumu (TÜİK) resmi web sitesindeki verilerden derlenmiştir. Faiz oranı; bankalar tarafından bir yıla kadar vadeli Türk Lirası cinsinden açılan mevduat hesaplarına uygulanan faiz oranlarının ortalamasıyla bulunmuştur. Döviz kuru, TCMB tarafından ilan edilen Dolar-Türk Lirası paritesi üzerinden hesaplanmıştır.

Tablo 3. Bağımsız Değişkenler

\begin{tabular}{|c|c|c|c|c|}
\hline YILLAR & $\begin{array}{l}\text { Enflasyon } \\
\text { (TÜFE) } \\
(\%)\end{array}$ & $\begin{array}{ll}\begin{array}{l}\text { DÖVIZ } \\
\text { (\$/TL) }\end{array} & \text { KURU } \\
\end{array}$ & $\begin{array}{l}\text { Kiş̧iBAŞI MİLLİ } \\
\text { GELIR }\end{array}$ & FAİZ ORANI (\%) \\
\hline 2005 & 7,72 & 1,34 & 9844 & 18,46 \\
\hline 2006 & 9,65 & 1,43 & 11389 & 16,38 \\
\hline 2007 & 8,39 & 1,3 & 12550 & 17,99 \\
\hline 2008 & 10,01 & 1,29 & 14001 & 17,84 \\
\hline 2009 & 6,50 & 1,55 & 13870 & 14,37 \\
\hline 2010 & 6,40 & 1,5 & 15860 & 9,26 \\
\hline 2011 & 10,50 & 1,67 & 18788 & 9,21 \\
\hline 2012 & 6,20 & 1,80 & 20880 & 10,06 \\
\hline 2013 & 7,40 & 1,90 & 23766 & 8,1 \\
\hline 2014 & 8,20 & 2,19 & 26489 & 9,85 \\
\hline 2015 & 8,80 & 2,72 & 29899 & 9,85 \\
\hline 2016 & 8,50 & 3,02 & 32904 & 11,01 \\
\hline
\end{tabular}

Kaynak: TÜİK (http://tuik.gov.tr/Start.do, Erişim tarihi : 01.03.2019).

\subsubsection{Bağımlı Değișkenler}

Çalışmada bağımlı değişken olarak sektörlerin sermaye yapısını gösteren kaldıraç oranı (Toplam Borçlar/Toplam Varlıklar) kullanılmıştır. Kaldıraç oranları, TCMB sektörel bilançolarındaki verilerden derlenmiştir. Avrupa Topluluğunda Ekonomik Faaliyetlerin Genel Sinıflandırılması (NACE) kriterleri kapsamında sinıflandırılan ve TCBM tarafindan 
bilançoları yayımlanan 9 alt sektörün bilançoları kullanılmıştır. Gönüllülük esasına dayalı olarak verilerini TCMB'ye gönderen imalat dışı sektör işletmelerinin verileri TCMB tarafindan birleştirilmekte ve tek bir bilanço olarak yayımlanmaktadır. Dolayısıyla elde edilen kaldıraç oranı, Tablo 2'de toplam sayıları verilen işletmelere ait verilerin birleştirilmesinden ortaya çıkan sektördeki tüm işletmelerin toplam borçlarının toplam varlıklara bölünmesi yoluyla bulunmuştur ki bu oran sektör ortalaması olarak kabul edilebilir.

Tablo 4. Bağımlı Değişkenler (TCMB İmalat Dışı Sektörler Kaldıraç Oranları (\%))

\begin{tabular}{|c|c|c|c|c|c|c|c|c|c|c|}
\hline & $\begin{array}{l}\text { Tarım } \\
\text { Orman } \\
\text { Balık- } \\
\text { çılık }\end{array}$ & $\begin{array}{l}\text { Madencilik } \\
\text { Ve } \\
\text { Taşocağı }\end{array}$ & $\begin{array}{l}\text { Elektrik, } \\
\text { Gaz, } \\
\text { Buhar } \\
\text { ve Sicak } \\
\text { Su } \\
\text { Üretimi }\end{array}$ & İnşaat & $\begin{array}{l}\text { Toptan } \\
\text { Perakende } \\
\text { Ticaret }\end{array}$ & $\begin{array}{l}\text { Konaklama } \\
\text { Ve Yiyecek } \\
\text { Hizmetleri }\end{array}$ & $\begin{array}{l}\text { Ulaştırma } \\
\text { Depolama } \\
\text { Haberleş. }\end{array}$ & $\begin{array}{l}\text { Gayrimen- } \\
\text { kul, } \\
\text { Kiralama } \\
\text { İş Faaliyet }\end{array}$ & Eğitim & Sağlık \\
\hline 2005 & 53,29 & 38,82 & 44,98 & 75,16 & 66,67 & 36,08 & 39,11 & 18,55 & 32,50 & 49,15 \\
\hline 2006 & 50,58 & 33,67 & 48,01 & 75,21 & 66,31 & 41,02 & 45,60 & 19,24 & 30,98 & 55,31 \\
\hline 2007 & 51,29 & 34,03 & 41,84 & 74,58 & 61,38 & 43,54 & 48,01 & 17,38 & 30,01 & 55,01 \\
\hline 2008 & 63,82 & 32,02 & 72,04 & 78,42 & 64,53 & 59,51 & 61,44 & 63,08 & 40,26 & 66,43 \\
\hline 2009 & 59,92 & 29,51 & 69,69 & 75,24 & 62,47 & 58,70 & 56,24 & 68,37 & 38,54 & 64,93 \\
\hline 2010 & 53,91 & 31,05 & 63,85 & 74,16 & 64,39 & 58,94 & 55,10 & 69,93 & 37,27 & 66,09 \\
\hline 2011 & 60,73 & 30,02 & 72,04 & 71,79 & 65,56 & 61,23 & 61,30 & 58,03 & 30,45 & 70,21 \\
\hline 2012 & 61,96 & 27,95 & 69,69 & 71,61 & 66,22 & 58,86 & 59,31 & 59,01 & 33,66 & 68,49 \\
\hline 2013 & 64,06 & 33,54 & 63,85 & 74,63 & 69,65 & 67,49 & 55,06 & 62,96 & 37,73 & 74,13 \\
\hline 2014 & 58,62 & 32,78 & 63,11 & 73,79 & 69,79 & 66,25 & 53,31 & 64,74 & 79,22 & 65,00 \\
\hline 2015 & 62,65 & 39,19 & 66,45 & 77,11 & 72,24 & 71,32 & 54,96 & 70,47 & 83,65 & 70,05 \\
\hline 2016 & 60,36 & 43,61 & 69,53 & 79,74 & 73,49 & 77,83 & 60,39 & 71,64 & 83,67 & 75,65 \\
\hline
\end{tabular}

Kaynak: TCMB Sektörel bilançoları, (www.tcmb.gov.tr , Erişim Tarihi: 01.02.2019).

\subsection{Uygulama ve Tanımlayıcı İstatistikler}

Temel makroekonomik parametrelerin sektörlerin sermaye yapılarını ne ölçüde etkilediğini tespit etmek için doğrusal regresyon analizi yapılmıştır. Analiz için SPSS 25 istatisik paket programı kullanılmıştır. İstatistiksel anlamlılık için $p<0.05$ değeri kullanılmıştır.

Analize konu olan parametrelere ilişkin tanımlayıcı istatistikler aşağıdaki tabloda gösterilmiştir. Tabloda, 12 yıl boyunca alt sektörler bazında elde edilen en düşük, en yüksek ve ortalama kaldıraç oranları yer almaktadır. Regresyon analizinde her yılın kaldıraç oranı ile ilgili yılın makroekonomik göstergeleri veri olarak kullanıldığından, bu tablodaki veriler sadece istatistiki bilgi verme amacını taşımaktadır. 
Tablo 5. Tanımlayıcı İstatistikler

\begin{tabular}{|c|c|c|c|c|c|}
\hline Değişkenler & $\mathbf{N}$ & Min. & Max. & Ortalama & Std. Sapma \\
\hline \multicolumn{6}{|l|}{ Bağımlı Değişkenler } \\
\hline Tarım, Ormancılık Balıkçılık & 12 & 50,58 & 64,06 & 58,4334 & 4,87 \\
\hline Madencilik Ve Taşocağı & 12 & 27,95 & 43,61 & 33,8492 & 4,56 \\
\hline Elektrik, Gaz, Buhar ve Sıcak Su Üret. & 12 & 41,84 & 72,04 & 62,0900 & 10,85 \\
\hline İnşaat & 12 & 71,61 & 79,74 & 75,1200 & 2,39 \\
\hline Toptan Perakende Ticaret & 12 & 61,38 & 73,49 & 66,8917 & 3,72 \\
\hline Konaklama Ve Yiyecek Hizmetleri & 12 & 36,08 & 77,83 & 58,3975 & 12,50 \\
\hline Ulaştırma Depolama Haberleşme & 12 & 39,11 & 61,44 & 54,1525 & 6,83 \\
\hline $\begin{array}{l}\text { Gayrimenkul, Kiralama İş Faaliyet. } \\
\text { Eğitim }\end{array}$ & $\begin{array}{l}12 \\
12\end{array}$ & $\begin{array}{l}17,38 \\
30,01\end{array}$ & $\begin{array}{l}71,64 \\
83,67\end{array}$ & $\begin{array}{l}53,6167 \\
46,4950\end{array}$ & $\begin{array}{l}21,67 \\
21,80\end{array}$ \\
\hline Sağlık & 12 & 49,15 & 75,65 & 65,0375 & 8,03 \\
\hline \multicolumn{6}{|l|}{ Bağımsız Değişkenler } \\
\hline TÜFE & 12 & 6,20 & 10,50 & 8,18 & $\overline{1,41}$ \\
\hline Döviz Kuru (\$/TL) & 12 & 1,29 & 3,02 & 1,8092 & 0,56 \\
\hline GSYIH & 12 & 9844,00 & 32904,00 & 19186,66 & 7619,34 \\
\hline Faiz Oranı & 12 & 8,10 & 18,46 & 12,69 & 3,99 \\
\hline
\end{tabular}

\subsection{Bulgular ve Tartışma}

Aşağıdaki tablolar yapılan regresyon analizi sonucunda ortaya çıkanregresyon modelinin katsayıları ve model anlamlılık değerleri yer almaktadır. Standardize katsayılar, regresyon modelinde bağımlı değişkeni açılamada anlamlı katkıları olan bağımsız değişkenleri göstermektedir. Tablodaki $\mathrm{t}$ ve $\mathrm{p}$ değerleri katsayıların anlamlılıkları ile ilgili bilgiler vermektedir.

Tablodaki $\mathrm{R}^{2}$ değeri bağımlı değişkendeki değişikliklerin ne kadarının bağımsız değişkenler tarafindan açıklandığını gösterir. Düzeltilmiş $\mathrm{R}^{2}$ değerleri bağımlı değişkendeki varyansın ne kadarının bă̆ımsız değişkenler tarafından açıklandığını göstermektedir.

Tabloda, regresyon modelinin anlamllık sonucunu gösteren tek yönlü varyans analizi (ANOVA; F) sonuçları da yer almaktadır. Modelin anlamlılı̆ı bağımlı değişkendeki varyansın model tarafindan ne kadar iyi açıklandığını belirtmektedir. Tablolardaki anlamlılık değeri $(p)$ istenen anlam seviyesinden ( 0.05 olarak belirlenmiştir) ne kadar küçükse regresyon modelinin bağımlı değişkendeki varyansı o kadar iyi açıklandığı anlaşılmaktadır 


\subsection{1. İnsanSağlı̆̆ı ve Sosyal Hizmet Faaliyeti Sektörünün Sermaye Yapısındaki Değişimlerde Temel Makroekonomik Göstergelerin Etkileri}

Aşağıdaki tabloda, yapılan regresyon analizi sonucunda sağlık sektörünün sermaye yapısındaki değişimlerde temel makroekonomik göstergelerin etkilerini gösteren sonuçlar yer almaktadır.

Tablo 6. Sağlık Sektörü İle İlgili Model Anlamlllık ve Regresyon Analizi Sonuçları

\begin{tabular}{|l|c|c|c|c|c|c|c|c|}
\hline \multicolumn{1}{|c|}{ Değişkenler } & B & SH & Beta & t & p & $\mathbf{R}^{2}$ & Düzeltilmiş R & F \\
\hline Enflasyon (TÜFE) \% &,- 165 & 1,789 &,- 029 &,- 093 &, 928 &, 001 &,- 099 &, 009 \\
\hline Döviz Kuru (TL) & 9,280 & 3,395 &, 654 & 2,733 &, 021 &, 654 &, 428 & 7,471 \\
\hline GSYH Değeri &, 001 &, 000 &, 780 & 3,941 &, 003 &, 608 &, 569 & 15,533 \\
\hline Faiz (TRY) & $-1,588$ &, 391 &,- 789 & $-4,058$ &, 002 &, 622 &, 584 & 16,464 \\
\hline
\end{tabular}

Regresyon katsayılarının anlamlalılık testleri incelendiğinde, bağımsız değişkenlerden GSYH $(\mathrm{p}=0.003<0.05)$ ve Faiz Oranı $(\mathrm{p}=0.002<0.05)$ değişkenlerinin sağlık sektörü sermaye yapısı üzerinde anlamlı etkisinin olduğu, diğer bağımsız değişkenlerin istatistiksel olarak anlamlı bir etkisinin olmadığı görülmektedir $(\mathrm{p}>0.05)$. Ayrıca $\mathrm{R}^{2}$ ve düzeltilmiş $\mathrm{R}^{2}$ değerleri incelendiğinde, sağlik sektörü sermaye yapısındaki \% 60,8'lik değişimin ve \%56,9'lük varyasın GSYH bağımsız değişkenine ve $\% 62,2$ 'lik değişimin ve $\% 58,4$ 'lük varyansın negatif yönde faiz oranı bağımsız değişkenine bağlı olduğu görülmektedir.

Sağlık sektöründe, GSYH arttıkça varlıkların finansmanında daha fazla yabancı kaynak kullanıldığı ancak faiz oranları arttığında yabnacı kaynak kullanım oranının azaldığı görülmektedir.

\subsubsection{Eğitim Sektörünün Sermaye Yapısındaki Değişimlerde Temel Makroekonomik Göstergelerin Etkileri}

Aşağıdaki tabloda, yapılan regresyon analizi sonucunda eğitim sektörünün sermaye yapısındaki değişimlerde temel makroekonomik göstergelerin etkilerini gösteren sonuçlar yer almaktadır.

Tablo 7. Eğitim Sektörü İle İlgili Model Anlamlılık ve Regresyon Analizi Sonuçları

\begin{tabular}{|l|c|c|c|c|c|c|c|c|}
\hline \multicolumn{1}{|c|}{ Değişkenler } & $\mathbf{B}$ & $\mathbf{S H}$ & $\mathbf{B e t a}$ & $\mathbf{t}$ & $\mathbf{p}$ & $\mathbf{R}^{2}$ & Düzeltilmiş R$^{2}$ & $\mathbf{F}$ \\
\hline Enflasyon (TÜFE) \% & 1,316 & 4,840 &, 086 &, 272 &, 791 & 0,007 & $-0,092$ & 0,074 \\
\hline Döviz Kuru (TL) & 34,583 & 5,363 &, 898 & 6,448 &, 000 & 0,806 & 0,787 & 41,579 \\
\hline GSYH Değeri &, 002 &, 000 &, 853 & 5,160 &, 000 & 0,853 & 0,727 & 26,626 \\
\hline Faiz (TRY) & $-2,114$ & 1,593 &,- 387 & $-1,327$ &, 214 & 0,150 & 0,065 & 1,761 \\
\hline
\end{tabular}

Regresyon katsayılarının anlamlılık testleri incelendiğinde, bağımsız değişkenlerden Döviz Kuru(p=0.000<0.05) ve GSYH $(\mathrm{p}=0.000<0.05)$ değişkenlerinin eğitim sektörü sermaye yapısı üzerinde anlamlı etkisinin olduğu, diğer bağımsız değişkenlerin istatistiksel olarak 
anlamlı bir etkisinin olmadığı görülmektedir ( $>>0.05$ ). Ayrıca $\mathrm{R}^{2}$ ve düzeltilmiş $\mathrm{R}^{2}$ değerleri incelendiğinde, eğitim sektörü sermaye yapısındaki \% 80,6’lık değişimin ve \%78,7'lik varyasın döviz kuru bağımsız değişkenine ve \%85,3'lük değişimin ve \%72,7'lik varyansın GSYH değişkenine bağlı olduğu görülmektedir.Veriler değerlendirildiğinde; GSYH ve döviz kuru arttıkça eğitim sektöründe varlıkların finansmanında daha fazla yabancı kaynak kullanıldı̆̆ı sonucuna ulaşılmaktadır.

\subsubsection{Gayrimenkul Faaliyetleri Sektörünün Sermaye Yapısındaki Değişimlerde Temel Makroekonomik Göstergelerin Etkileri}

Aşağıdaki tabloda, yapılan regresyon analizi sonucunda gayrimenkul faaliyetleri sektörünün sermaye yapısındaki değişimlerde temel makroekonomik göstergelerin etkilerini gösteren sonuçlar yer almaktadır.

Tablo 8. Gayrimenkul Faaliyetleri Sektörü İle İlgili Model Anlamlılık ve Regresyon Analizi Sonuçları

\begin{tabular}{|c|c|c|c|c|c|c|c|c|}
\hline Değișkenler & B & SH & Beta & $\mathbf{t}$ & $\mathbf{p}$ & $\overline{\mathbf{R}^{2}}$ & Düzeltilmiş $R^{2}$ & $\mathbf{F}$ \\
\hline Enflasyon (TÜFE) \% & $-3,151$ & 4,725 &,- 206 &,- 667 &, 520 & 0,043 & $-0,053$ & 0,445 \\
\hline Döviz Kuru (TL) & 21,497 & 10,020 & ,561 & 2,145 & ,058 & 0,315 & 0,247 & 4,603 \\
\hline GSYH Değeri & ,002 & 001 & ,668 & 2,839 & ,018 & 0,446 & 0,391 & 8,063 \\
\hline Faiz (TRY) & $-3,916$ & 1.190 &,- 721 & $-3,290$ & ,008 & 0,520 & 0,472 & 10,874 \\
\hline
\end{tabular}

Regresyon katsayılarının anlamlalılık testleri incelendiğinde, bağımsız değişkenlerden faiz oranı $(\mathrm{p}=0.008<0.05)$ ve GSYH $(\mathrm{p}=0.018<0.05)$ değişkenlerinin gayrimenkul faaliyetleri sektörü sermaye yapısı üzerinde anlamlı etkisinin olduğu, diğer bağımsız değişkenlerin istatistiksel olarak anlamlı bir etkisinin olmadığı görülmektedir $(p>0.05)$. Ayrıca $R^{2}$ ve düzeltilmiş $\mathrm{R}^{2}$ değerleri incelendiğinde, gayrimenkul faaliyetleri sektörü sermaye yapısındaki \% 52'lik değişimin ve \%47,2'lik varyansın negatif yönde döviz kuru bağımsız değişkenine, \%44,6'lık değişimin ve \%39,1'likvaryansın GSYH değişkenine bağlı olduğu görülmektedir.

Veriler değerlendirildiğinde; GSYH arttıkça gayrimenkul faaliyetleri sektöründe varlıkların finansmanında daha fazla yabancı kaynak kullanıldığı ancak faiz oranındaki artışın yabanıı kaynak kullanımını azalttığı sonucuna ulaşılmaktadır. Bu sonuçlarla gayrikenkul sektöründe sermaye yapısını etki eden faktörlerin sağlık sektörü ile paralellik gösterdiği görülmektedir.

\subsubsection{Ulaştırma ve Depolama Faaliyetleri Sektörünün Sermaye Yapısındaki Değişimlerde Temel Makroekonomik Göstergelerin Etkileri}

Aşağıdaki tabloda, yapılan regresyon analizi sonucunda ulaştırma ve depolama faaliyetleri sektörünün sermaye yapısındaki değişimlerde temel makroekonomik göstergelerin etkilerini gösteren sonuçlar yer almaktadır. 
Tablo.9. Ulaştırma ve Depolama Sektörü Model Anlamlılık ve Regresyon Analizi Sonuçları

\begin{tabular}{|l|c|c|c|c|c|c|c|c|}
\hline \multicolumn{1}{|c|}{ Değişkenler } & B & SH & Beta & $\mathbf{t}$ & $\mathbf{p}$ & $\mathbf{R}^{2}$ & Düzeltilmiş R & $\mathbf{F}$ \\
\hline Enflasyon (TÜFE) \% &, 422 & 1,518 &, 088 &, 278 &, 787 & 0,008 & $-0,092$ & 0,077 \\
\hline Döviz Kuru (TL) & 4,489 & 3,547 &, 372 & 1,266 &, 234 & 0,372 & 0,138 & 1,602 \\
\hline GSYH Değeri &, 000 &, 000 &, 513 & 1,890 &, 088 & 0,513 & 0,263 & 3,574 \\
\hline Faiz (TRY) &,- 948 &, 451 &,- 553 & $-2,101$ &, 062 & 0,553 & 0,306 & 4,415 \\
\hline
\end{tabular}

Regresyon katsayılarının anlamlalılık testleri incelendiğinde, bağımsız değişkenlerden hiçbirinin ulaştırma ve depolama faaliyetleri sektörü sermaye yapısı üzerinde anlamlı bir etkisinin olmadğı görülmektedir.

\subsubsection{Toptan ve Perakende Ticaret Sektörünün Sermaye Yapısındaki Değişimlerde Temel Makroekonomik Göstergelerin Etkileri}

Aşağıdaki tabloda, yapılan regresyon analizi sonucunda toptan ve perakende ticaret sektörünün sermaye yapısındaki değişimlerde temel makroekonomik göstergelerin etkilerini gösteren sonuçlar yer almaktadır.

Tablo 10. Toptan ve Perakende Ticaret Sektörü İle İlgili Model Anlamlılık ve Regresyon Analizi Sonuçları

\begin{tabular}{|l|c|c|c|c|c|c|c|c|}
\hline \multicolumn{1}{|c|}{ Değişkenler } & $\mathbf{B}$ & $\mathbf{S H}$ & $\mathbf{B e t a}$ & $\mathbf{t}$ & $\mathbf{p}$ & $\mathbf{R}^{\mathbf{2}}$ & Düzeltilmiş R$^{\mathbf{2}}$ & $\mathbf{F}$ \\
\hline Enflasyon (TÜFE) \% &, 326 &, 823 &, 124 &, 396 &, 700 & 0,015 & $-0,083$ & 0,157 \\
\hline Döviz Kuru (TL) & 5,569 &, 940 &, 892 & 6,245 &, 000 & 0,796 & 0,775 & 38,995 \\
\hline GSYH Değeri &, 000 &, 000 &, 860 & 5,318 &, 000 & 0,739 & 0,713 & 28,274 \\
\hline Faiz (TRY) & $-0,482$ &, 253 &,- 516 & $-1,907$ &, 086 & 0,267 & 0,193 & 3,637 \\
\hline
\end{tabular}

Regresyon katsayılarının anlamlalılık testleri incelendiğinde, bağımsız değişkenlerden Döviz Kuru( $\mathrm{p}=0.000<0.05)$ ve GSYH $(\mathrm{p}=0.000<0.05)$ değişkenlerinin toptan ve perakende ticaret sektörü sermaye yapısı üzerinde anlamlı etkisinin olduğu, diğer bağımsız değişkenlerin istatistiksel olarak anlamlı bir etkisinin olmadığ görülmektedir $(p>0.05)$. Ayrıca $R^{2}$ ve düzeltilmiş $\mathrm{R}^{2}$ değerleri incelendiğinde, toptan ve perakende ticaret sektörü sermaye yapısındaki \% 79,6'lk değişimin ve \%77,5' lik varyansın döviz kuru bağımsız değiş̧kenine ve \%73,9'lük değişimin ve \%71,3'lük varyansın GSYH değiş̧kenine bağl1 olduğu görülmektedir.

Veriler değerlendirildiğinde; GSYH ve döviz kuru arttıkça toptan ve perakende sektöründe varlıkların finansmanında daha fazla yabancı kaynak kullanıldığı gözlemlenmektedir. $\mathrm{Bu}$ sonuçlarla, toptan ve perakende sektöründe sermaye yapısını etkileyen faktörlerin eğitim sektörü ile parallelik gösterdiği söylenebilir. 


\subsection{6. İnşaat Sektörünün Sermaye Yapısındaki Değişimlerde Temel Makroekonomik Göstergelerin Etkileri}

Aşağıdaki tabloda, yapılan regresyon analizi sonucunda inşaat sektörünün sermaye yapısındaki değişimlerde temel makroekonomik göstergelerin etkilerini gösteren sonuçlar yer almaktadır.

Tablo 11. İnşaat Sektörü İle İlgili Model Anlamlılık ve Regresyon Analizi Sonuçları

\begin{tabular}{|l|c|c|c|c|c|c|c|c|}
\hline \multicolumn{1}{|c|}{ Değişkenler } & $\mathbf{B}$ & $\mathbf{S H}$ & $\mathbf{B e t a}$ & $\mathbf{t}$ & $\mathbf{p}$ & $\mathbf{R}^{\mathbf{2}}$ & D̈̈zeltilmiş R & $\mathbf{F}$ \\
\hline Enflasyon (TÜFE) \% &, 444 &, 514 &, 264 &, 864 &, 408 & 0,070 & $-0,024$ & 0,747 \\
\hline Döviz Kuru (TL) & 1,738 & 1,217 &, 412 & 1,428 &, 184 & 0,169 & 0,086 & 2,040 \\
\hline GSYH Değeri & 8,780 &, 000 &, 280 &, 922 &, 378 & 0,078 & $-0,014$ & 0,850 \\
\hline Faiz (TRY) &, 181 &, 181 &, 301 & 1,000 &, 341 & 0,301 & 0,091 & 0,999 \\
\hline
\end{tabular}

Regresyon katsayılarının anlamlalılık testleri incelendiğinde, bağımsız değişkenlerden hiçbirinin inşaat sektörü sermaye yapısı üzerinde anlamlı bir etkisinin olmadğı görülmektedir.

\subsubsection{Elektrik, Gaz, Buhar ve İklimlendirme Üretimi ve DağıtımıSektörünün Sermaye Yapısındaki Değişimlerde Temel Makroekonomik Göstergelerin Etkileri}

Aşağıdaki tabloda, yapılan regresyon analizi sonucunda elektrik, gaz, buhar ve iklimlendirme üretimi ve dağıtımı sektörünün sermaye yapısındaki değişimlerde temel makroekonomik göstergelerin etkilerini gösteren sonuçlar yer almaktadır.

Tablo 12. Elektrik, Gaz, Buhar Üretimi Sektörü İle İlgili Model Anlamlılık ve Regresyon Analizi Sonuçları

\begin{tabular}{|c|c|c|c|c|c|c|c|c|}
\hline Değișkenler & B & SH & Beta & $\mathbf{t}$ & p & & Düzeltilmiş $\mathbf{R}^{2}$ & $\mathbf{F}$ \\
\hline Enflasyon (TÜFE) \% &,- 136 & 2,418 &,- 018 &,- 056 & ,956 & 0,00 & $-0,100$ & 0,03 \\
\hline Döviz Kuru (TL) & 7,966 & 5,517 & ,415 & 1,444 & ,179 & 0,173 & ,090 & 2,085 \\
\hline GSYH Değeri & ,001 & ,000 & ,527 & 1,960 & ,078 & 0,278 & 0,205 & 3,843 \\
\hline Faiz (TRY) & $-1,659$ & ,682 & $\begin{array}{l}-, 610 \\
\end{array}$ & $-2,432$ &, 035 & 0,372 & 0,309 & 5,916 \\
\hline
\end{tabular}

Regresyon katsayılarının anlamlalılık testleri incelendiğinde, bağımsız değişkenlerden sadece faiz oranı $(\mathrm{p}=0.035<0.05)$ değişkeninin elektrik, gaz, buhar ve iklimlendirme üretimi ve dağıtımı sektörü sermaye yapısı üzerinde negatif yönlü anlamlı etkisinin olduğu, diğer bağımsız değişkenlerin istatistiksel olarak anlamlı bir etkisinin olmadığı görülmektedir $(\mathrm{p}>0.05)$. Ayrıca $\mathrm{R}^{2}$ ve düzeltilmiş $\mathrm{R}^{2}$ değerleri incelendiğinde, elektrik, gaz, buhar ve iklimlendirme üretimi ve dağıtımı sektörü sermaye yapısındaki \% 37,2'lik değiş̧imin ve $\% 30,9$ 'luk varyansın faiz oranı değişkenine bağlı olduğu görülmektedir. 
Veriler değerlendirildiğinde; faiz oranı arttıkça elektrik, gaz, buhar ve iklimlendirme üretimi ve dağıtımı sektörü sektöründe varlıkların finansmanında daha az yabancı kaynak kullanıldığı gözlemlenmektedir.

\subsubsection{Madencilik ve Taş Ocakçılığı Sektörünün Sermaye Yapısındaki Değişimlerde Temel Makroekonomik Göstergelerin Etkileri}

Aşağıdaki tabloda yapılan regresyon analizi sonucunda madencilik ve taş ocakçılığ sektörünün sermaye yapısındaki değişimlerde temel makroekonomik göstergelerin etkilerini gösteren sonuçlar yer almaktadır.

Tablo 13. Madencilik ve Taş Ocakçılığı Sektörü İle İlgili Model Anlamlılık ve Regresyon Analizi Sonuçları

\begin{tabular}{|l|c|c|c|c|c|c|c|c|}
\hline \multicolumn{1}{|c|}{ Değişkenler } & B & SH & Beta & $\mathbf{t}$ & $\mathbf{p}$ & $\mathbf{R 2}$ & Düzeltilmiş R2 & F \\
\hline Enflasyon (TÜFE) \% &, 716 &, 992 &, 223 &, 722 &, 487 & 0,050 & $-0,045$ & 0,521 \\
\hline Döviz Kuru (TL) & 4,943 & 2,016 &, 613 & 2,452 &, 034 & 0,376 & 0,313 & 6,013 \\
\hline GSYH Değeri &, 000 &, 000 &, 442 & 1,557 &, 150 & 0,195 & 0,115 & 2,425 \\
\hline Faiz (TRY) &, 135 &, 359 &, 118 &, 375 &, 715 & 0,14 & $-0,085$ & 0,141 \\
\hline
\end{tabular}

Regresyon katsayılarının anlamlalılık testleri incelendiğinde, bağımsız değişkenlerden sadece döviz kuru( $\mathrm{p}=0.034<0.05)$ değişkeninin madencilik ve taş ocakçıllıği sektörü sermaye yapısı üzerindeanlamlı etkisinin olduğu, diğer bağımsız değişkenlerin istatistiksel olarak anlamlı bir etkisinin olmadığı görülmektedir $(\mathrm{p}>0.05)$. Ayrıca $\mathrm{R}^{2}$ ve düzeltilmiş $\mathrm{R}^{2}$ değerleri incelendiğinde, madencilik ve taş ocakçılığı sektörü sermaye yapısındaki \% 37,6 'lık değişimin ve \%31,3'lük varyansındöviz kuru değişkenine bağlı olduğu görülmektedir.

Veriler değerlendirildiğinde; faiz oranı arttıkça madencilik ve taş ocakçıllı̆ 1 sektörü sektöründe varlıkların finansmanında daha fazla yabancı kaynak kullanıldı̆̆ gözlemlenmektedir.

\subsubsection{Tarım, Orman ve Balıkçılık Sektörünün Sermaye Yapısındaki Değişimlerde Temel Makroekonomik Göstergelerin Etkileri}

Aşağıdaki tabloda yapılan regresyon analizi sonucunda tarım, orman ve balıkçılık sektörünün sermaye yapısındaki değişimlerde temel makroekonomik göstergelerin etkilerini gösteren sonuçlar yer almaktadır. 
Tablo 14. Tarım, Orman ve Balıkçılık Sektörü İle İlgili Model Anlamlılık ve Regresyon Analizi Sonuçları

\begin{tabular}{|l|c|c|c|c|c|c|c|c|}
\hline \multicolumn{1}{|c|}{ Değişkenler } & B & SH & Beta & $\mathbf{t}$ & $\mathbf{p}$ & $\mathbf{R 2}$ & Düzeltilmiş R2 & F \\
\hline Enflasyon (TÜFE) \% &, 087 & 1,087 &, 025 &, 080 &, 938 & 0,001 & $-0,099$ & 0,006 \\
\hline Döviz Kuru (TL) & 3,872 & 2,435 &, 449 & 1,590 &, 143 & 0,222 & 0,122 & 2,528 \\
\hline GSYH Değeri &, 000 &, 000 &, 586 & 2,288 &, 045 & 0,344 & 0,278 & 5,233 \\
\hline &,- 626 &, 332 &,- 512 & $-1,884$ &, 089 & 0,262 & 0,188 & 3,548 \\
Faiz (TRY) & & & & & & & & \\
\hline
\end{tabular}

Regresyon katsayılarının anlamlalılık testleri incelendiğinde, bağımsız değişkenlerden GSYH $(p=0.045<0.05)$ değişkeninin tarım, orman ve balıkçılık sektörü sermaye yapısı üzerinde anlamlı etkisinin olduğu, diğer bağımsız değişkenlerin istatistiksel olarak anlamlı bir etkisinin olmadığı görülmektedir $(\mathrm{p}>0.05)$. Ayrıca $\mathrm{R}^{2}$ ve düzeltilmiş $\mathrm{R}^{2}$ değerleri incelendiğinde; tarım, orman ve balıkçılık sektörü sermaye yapısındaki \% 34,4'lük değişimin ve \%26,2'lik varyansın GSYH bağımsız değişkenine bağlı olduğu görülmektedir.

Veriler değerlendirildiğinde; GSYH arttıkça tarım, orman ve balıkçılık sektöründe varlıkların finansmanında daha fazla yabancı kaynak kullanıldığı gözlemlenmektedir.

\subsubsection{Konaklama ve Yiyecek Hizmeti Sektörünün Sermaye Yapısındaki Değişimlerde Temel Makroekonomik Göstergelerin Etkileri}

Aşağıdaki tabloda yapılan regresyon analizi sonucunda tarım, orman ve balıkçılık sektörünün sermaye yapısındaki değişimlerde temel makroekonomik göstergelerin etkilerini gösteren sonuçlar yer almaktadır.

Tablo 15. Konaklama, Yiyecek Hizmeti Sektörü İle İlgili Model Anlamlılık ve Regresyon Analizi Sonuçları

\begin{tabular}{|c|c|c|c|c|c|c|c|c|}
\hline Değişkenler & B & SH & Beta & $\mathbf{t}$ & $\mathbf{p}$ & $\overline{\mathbf{R}^{2}}$ & Düzeltilmiş $\mathbf{R}^{2}$ & $\mathbf{F}$ \\
\hline Enflasyon (TÜFE) \% &,- 221 & 2,785 &,- 025 &,- 079 & 9,938 & 0,001 & $-0,099$ & 0,006 \\
\hline Döviz Kuru (TL) & 17,741 & 4,162 & 803 & 4,263 & ,002 & 0,645 & 0,610 & $\overline{18,170}$ \\
\hline GSYH Değeri & ,001 & ,000 & ,894 & 6,317 &, 000 & 0,800 & 0,780 & 39,901 \\
\hline Faiz (TRY) & $-2,351$ & 655 &,-- 750 & $-3,588$ &, 005 & 0,750 & 0,563 & 12,872 \\
\hline
\end{tabular}

Regresyon katsayılarının anlamlalılık testleri incelendiğinde, bağımsız değişkenlerden Döviz Kuru( $\mathrm{p}=0.002<0.05)$ ve GSYH $(\mathrm{p}=0.000<0.05)$ değişkenlerinin konaklama ve yiyecek hizmetleri sektörü sermaye yapısı üzerinde anlamlı etkisinin olduğu, diğer bağımsız değişkenlerin istatistiksel olarak anlamlı bir etkisinin olmadığ görülmektedir $(p>0.05)$. Ayrıca $\mathrm{R}^{2}$ ve düzeltilmiş $\mathrm{R}^{2}$ değerleri incelendiğinde, konaklama ve yiyecek hizmetleri sektörü sermaye yapısındaki \% 80'lik değişimin ve \%78'lik varyansınGSYH bağımsız değişkenine ve \%64,5'lük değişimin ve \%61'likvaryansındöviz kuru değişkenine bağlı olduğu görülmektedir.

Veriler değerlendirildiğinde; GSYH ve döviz kuru arttıkça konaklama ve yiyecek hizmetleri sektöründe varlıkların finansmanında daha fazla yabancı kaynak kullanıldığ 
gözlemlenmektedir. Bu sonuçlarla, konaklama ve yiyecek hizmetleri sektöründe sermaye yapısını etkileyen faktörlerin, eğitim ile toptan ve perakende sektörleri ile paralellik gösterdiği söylenebilir.

\section{SONUÇ}

İşletmeler varlıkların finansmanında özkaynakların yanında yabancı kaynakları da kullanmaktadır. Varlıkların finansmanında özkaynak ve yabancı kaynak dağılımını gösteren sermaye yapısı sektörlere göre farklı etkenlerden etkilenir. Bu çalışmada regresyon analizi kullanılarak temel makroekonomik göstergelerin sermaye yapısı üzerindeki etkisi araştırmak için T.C.M.B. sektörel bilançoları kullanılmıştır. Türkiye'de temel makroekonomik göstergelerin imalat dışı sektörlerin sermaye yapısı üzerindeki etkisini araştıran bir çalışma olmaması nedeniyle çalışmanın kapsamına imalat dışı sektörler alınmıştır. Yapılan regresyon analizi sonucunda; inşaat sektörü ile ulaştırma ve depolama faaliyetleri sektörünün sermaye yapısındaki değişimler üzerinde temel makroekonomik göstergelerin anlamlı bir etkisinin olmadığ1 tespit edilmiştir. Diğer imalat dışı sektörlerde; elektrik, gaz, buhar ve iklimlendirme üretimi ve dağıtımı ile madencilik ve taş ocakçılığı sektörü dışındaki tüm sektörlerde GSYH'nın sermaye yapısı üzerinde anlamlı etkisinin olduğu görülmüştür. GSYH arttıkça işletmelerin daha fazla yabancı kaynak kullandıkları sonucuna ulaşılmıştır. Bunun nedeni, GSYH'nın artışı ile birlikte işletmelerin artan kaynak ihtiyacının karşılanmasında özkaynakların yanında yabancı kaynak kullanımına da yönemleri olabilir. Sağlı, gayrimenkul faaliyetleri ile elektrik, gaz, buhar ve iklimlendirme üretimi sektörlerinin sermaye yapısındaki değişimler üzerinde faiz oranının negatif yönde anlamlı etkisinin olduğu tespit edilmiştir. Bu sektörlerde faiz oranının artması ile birlikte yabancı kaynak kullanımı düşmekte, özkaynak kullanımı artmaktadır. Faiz oranının artışı ile birlikte yabancı kaynak maliyetinde artış meydana gelmekte ve işletmelerin özkaynaklara daha fazla ağırlık vermelerine neden olmaktadır. Ayrıca eğitim, toptan ve perakende ticaret, madancilik ve taş ocakçıllğı ile konaklama ve yiyecek hizmetleri sektörlerinin sermaye yapıları üzerinde döviz kurunun anlamlı etkisinin olduğu tespit edilmiştir. Bu sektörlerde döviz kurunun artmasıyla birlikte işletmelerin yabancı kaynak kullanımında artış olduğu tespit edilmiştir. TÜFE'nin imalat dışı sektörlerin hiçbirinin sermaye yapısı değişimleri üzerinde anlamlı bir etkisine rastlanmamıştır.

Sermaye yapısındaki değişmelerde temel makroekonomik faktörlerin etkisi ile birlikte işletmeye özgü faktörlerin etkisinin birlikte incelenmesi ayrı bir çalışmanın konusu olabilir. Aynı sektör içerisinde yer alan büyük işletmelerin sermaye yapısına makroekonomik faktörlerin etkisinde farklılaşma olup olmadığı bir başka çalışmanın konusu olabilir.

Bu çalışmanın kapsamına, imalat dışı sektörlerden 12 yıllık sektörel bilançolarına ulaşılan sektörler dahil edilmiştir. Tam verilerine ulaşılamayan sektörlerin çalışma kapsamına alınamaması ve 2016 yılından sonraki sektörel bilançoların henüz yayınlanmamış olması bu çalışmanın kısıtlarındandır. TCMB 2017 yılında 2014-2016 yıllarına ait sektörel bilançoları yayınlamış, 2018 yılında yayınlaması gereken 2015-2017 yıllarına ait sektörel bilançoları ileri bir tarihe ertelediğini duyurmuştur. 


\section{KAYNAKLAR}

Abdioğlu, N. - Deniz, D. (2015), "Borsa İstanbul'da İşlem Gören İmalat Sanayi Şirketlerinin Sermaye Yapılarının Firmaya Özgü Belirleyicileri”, Sosyoekonomi Dergisi, C: 23(26), ss.195-213.

Adjunct, S. W - Eidet, A. - Frydenberg, S.\&Grosås, T. C. (2008), "InvestigatingtheCapitalStructure of UK Real EstateCompanies", Journal of PropertyResearch, V: 25(1), pp.61-87.

Akkaya, C.(2008), “Sermaye Yapısı, Varlık Verimliliği ve Karlılık: İMKB'de Faaliyet Gösteren Deri-Tekstil Sektörü İşletmeleri Üzzerine Bir Uygulama”, Erciyes Üniversitesi İktisadi ve İdari Bilimler Fakültesi Dergisi, C: 30, ss.1-13

Anwar, W. (2012),“Cross-IndustryDeterminants of CapitalStructure: EvidencefromPakistani Data", International Journal of Management andInnovation, V: 4(1): pp.79-86.

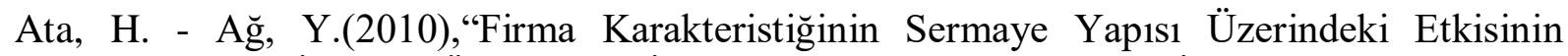
Analizi”, İstanbul Üniversitesi İktisat Fakültesi Ekonometri ve İstatistik Dergisi, C:11, ss.45-60.

Ay, F. (2018), "Sermaye Yapısını Etkileyen Faktörler: Borsa İstanbul'da İşlem Gören Çimento Şirketleri Üzerine Bir Uygulama”, Marmara Üniversitesi Sosyal Bilimler Enstitüsü, Yüksek Lisans Tezi.

Barbosa, C. -Costa, C. - Funchal, B. (2012), "Theeffects of Privatization on theCapitalStructure of BrazilianFirms", AppliedEconomicsLetters, V:19, pp. 11891192.

Başaran, Ü. (2008), “IMMKB'de İşlem Gören Otomotiv ve Otomotiv Yan Sanayi İşletmelerinin Sermaye Yapısı Kararlarını Etkileyen Faktörlerin Analizi, Yayımlanmamış YüksekLisans Tezi, Zonguldak Karaelmas Üniversitesi Sosyal Bilimler Enstitüsü, Zonguldak.

Bevan, A. - Danbolt, J. (2002), "CapitalStructuresanditsDeterminants in the UK-a Decompositional Analysis”, Applied Financial Economics, V: 12, pp.159 - 170.

Brealey, R. - Myers, Steward. - Marcus, A. (1999), "İşletme Finansının Temelleri”, Çev. Ünal Bozkurt, Türkan Arıkan, Hatice Doğukanlı.,Literatür Yayınları, İstanbul.

Clark, B, Francis, B. - Hasan, I. (2009), "Do FirmsAdjustTowardsTargetCapitalStructures? Some International Evidence", Lally School of Management andTechnology of RensselaerPolitechnikInstitute in TroyWorkingPaper Series.

Cortez, M.A. - Susanto, S.(2012), “TheDeterminants of CorporateCapitalStructure: EvidencefromJapaneseManufacturingCompanies", Journal of International Business Research, V:11(3), pp. 121-134. 
De Mederios, O.R. - Daher, C.E. (2005),"TestingStaticTradeoffAgainstPeckingOrderModels of CapitalStructure in BrazilianFirms.

Demirhan, D.( 2009), “Sermaye Yapısını Etkileyen Firmaya Özgü Faktörlerin Analizi: İMKB Hizmet Firmaları Üzerine Bir Uygulama”, Ege Akademik Bakış, C: 9(2), ss.677-697.

Fama, E. F. (1980), “AgencyProblemsAndTheTheory of theFirm”, TheJournalEconomics, V: 88(2), pp. 288-307.

Görg, H. - Strobl, E. (2001), “CapitalStructureandLabourDemand: FurtherEvidence, AppliedEconomicsLetters”, V:8, pp.719-723.

Halaç, U. - Durak, M.(2013),“İMKB’de İşlem Gören İşletmeler için Para Politikası ve Sermaye Yapısı İlişkisi”, Ege Akademik Bakış, C:13(4), ss. 497-504.

İsmail, M. - Eldomiaty, T. (2004). "BayesianIdentification of thePredictorsforCapitalStructure in Egypt", Advancesand Applications in Statistics, V: 4(2), pp. 193-212.

Karadeniz, E.(2008).“Türk Konaklama İşletmelerinde Sermaye Yapısını Etkileyen Faktörlerini Analizi”, Çukurova Üniversitesi Sosyal Bilimler Enstitüsü, Yüksek Lisans Tezi.

Karadeniz, E., Kaplan, F.- Günay, F. (2016), "Sermaye Yapısı Kararlarının Kârlılığa Etkisi: Borsa İstanbul Turizm Şirketlerinde Bir Araştırma", Seyahat ve Otel İşletmeciliği Dergisi,C:13(3).

Kısakürek, M. - Aydın, Y. (2013), "İşletmelerde Sermaye Yapısı ve Karlılık Arasındaki İlişkinin Analizi: 1992-2011 Yılları Arası Finansal Krizler Odaklı BİST’te Bir Uygulama”, C.Ü. İktisadi ve İdari Bilimler Dergisi, C:14 (2), ss.97-115.

Lööf, H. (2003), "Dynamic Optimal CapitalStructureandTechnologicalChang, Center forEuropeanEconomicResearch", DiscussionPaper pp.3-6

Medeiros, Ribeiro D. -Daher, Elias (2004), “TestingPeckingOrderTheory of CapitalStructure in BrazilianFirms", WorkingPaperSeries, V:12(4), pp.150-175.

Myers, S. C. (1977), "Determinants of CorporateBorrowing, Journal of Financial Economics", V:5, pp.147-175.

Okuyan, A. - Taşc1, H. (2013), “İMKB'de İşlem Gören Reel Sektör İşlemelerinde Sermaye Yapısının Belirleyicileri”, Ekonomik Yaklaşım, C:21(76), ss. 55-72.

Öcal, F. (2018), "TCMB İmalat Sanayi Sektörel Bilançoları Kullanılarak İktisadi Parametrelerin Sermaye Yapısına Etkisi Üzerine Bir Uygulama”, Gazi Üniversitesi Sosyal Bilimler Enstitüsü, Yüksek Lisans Tezi. 
Sarığlu, S. Karun, E. - Güzeldere, H. (2013), “Sermaye Yapısının Belirleyicileri: İMKB'de İşlem Gören Çimento, Otomotiv ve BilişimSektörlerinin Sermaye Yapısı Analizi”, Ege Akedemik Bakış, C:13(4), ss.481.

Sheikh, N.A. - Wang, Z. (2011), "DeterminantsCapitalStructure, An EmpricalStudy of Firms in ManifacturingIndustry of Pakistan”, Managerial Finance, V: 37(2),pp. 117-133.

Şahin, E. (2012). “IMMKB’de İşlem Gören Spor Firmalarının Sermaye Yapısının Belirleyicileri Üzerine Bir Analiz”, Niğde Üniversitesi Sosyal Bilimler Enstitüsü, Yüksek Lisans Tezi.

Takbaş, H.(2018), "Şirketlerin Sahiplik Yapısı İle Sermaye Yapısı Arasındaki İlişki: Türkiye Uygulaması”, Karabük Üniversitesi Sosyal Bilimler Enstitüsü, Yüksek Lisans Tezi.

Terim, B. - Kayalı, C. (2009), "Sermaye Yapısını Belirleyici Etmenler: Türkiye'de İmalat Sanayi Örneği”, Celal Bayar Üniversitesi S.B.E, C: 7(1), ss.125-154.

Titman, S. - Wessels, R. (1988), “TheDeterminants of CapitalStructureChoice”, Journal of Finance, V: 43, pp. 1-19.

Topal, Y. (2006),“İMKB’ye Kayıtlı İşletmelerin Sermaye Yapıları ve Finansal Kaldıraç Oranlarının Karlılıklarına Etkisi”, Erciyes Üniversitesi ktisadi ve dari Bilimler Fakültesi Dergisi, C: 27, Temmuz-Aralık, ss. 45-70.

Vasiliou, D.- Daskalakis, N.(2009), "BehavioralCapitalStructure: Is theNeoclassicalParadigmThreatened? EvidencefromtheField", TheJournal Of Behavioral Finance, V: 10, pp.19-32.

Yener, E. - Karakuş, R.(2012), "Sermaye Yapısı ve Firma Değeri İlişkisinin Farklı Aktif Büyüklüklerde Karşılaştırmalı İncelenmesi: İMKB 100 Firmaları Üzerine Bir Uygulama", Gazi Üniversitesi İktisadi ve İdari Bilimler Fakültesi Dergisi C:14(2), ss.75-98. 
